\title{
PARADIGMA TRANSMISI ILMU PENGETAHUAN ISLAM KE RUANG PERADABAN GLOBAL
}

\author{
Sudirman M. Johan
}

\begin{abstract}
In the $5^{\text {th }}$ or $6^{\text {th }}$ century $\mathrm{BCE}$, the Greek had established a communication network with the ancient East, especially with Egypt and Babylonia. The fusion between Greeks and the Eastern thought was more and more seen after Alexander's expansion in Egypt, so that Alexandria there became a center of melting between the Western and Eastern civilization. After the decline of Islamic civilization, there was likely separation between religion and reason as well as ignoring of Western civilization. For re-advancing of Islamic civilization, there are some steps can be passed i.e. rapprochement that is usually so-called epistemological re-integration.
\end{abstract}

Key words: science, civilization, Islamic world, and the West.

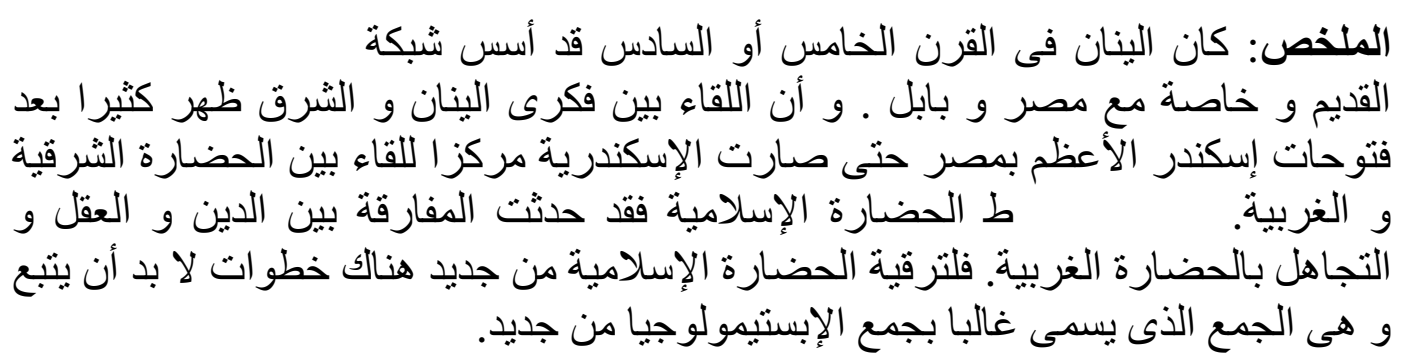

I

Pada abad ke 5 atau abad ke 6 SM, bangsa Yunani telah membentuk jaringan komunikasi dengan bangsa Timur kuno, terutama bangsa Mesir dan Babilonia. Dari kedua bangsa Timur inilah orang Yunani mempelajari ilmu hitung, ilmu ukur dan astronomi. Oleh bangsa Mesir dan Babilonia, ilmu-ilmu itu dikembangkan serta dipraktikkan di istana raja-raja. Kemudian oleh bangsa Yunani, ilmu-ilmu itu dikembangkan secara sistematis. Usaha tersebut telah menggambarkan sifat rasionalisasi dalam upaya mencari jawaban yang rasional tentang problem alam jagat raya. ${ }^{1}$ Akhirnya bangsa Yunani melahirkan ide-ide dan pemikiran yang bersifat ilmiah dalam mewujudkan suatu peradaban manusia di dataran Eropa.

Pertemuan alam pikiran Yunani dengan alam pikiran bangsa Timur semakin terlihat, setelah Alexander melakukan ekspansi ke Mesir, sehingga kota Iskandaria di Mesir pun menjadi pusat pertemuan peradaban Barat dan peradaban Timur. Yunani mempunyai keunggulan dalam bidang ilmu pengetahuan, sementara bangsa Timur memiliki kepercayaan yang gaib dan di dalamnya terdapat unsur mistik dan agama. Kedua unsur peradaban itu menyatu dan membuahkan suatu pemikiran yang tersebar di Iskandaria. ${ }^{2} \mathrm{Hal}$ ini terbukti dengan lahirnya pemikir-pemikir besar seperti Euclide, Galinus, Archimides, Platemius, dan pemikir lainnya. 
Perkembangan pengetahuan semenjak abad pertama Masehi sampai abad ke $6 \mathrm{M}$ berkembang pesat, sehingga Iskandaria menjadi Mercusuar ilmu pengetahuan. Iskandaria dalam perkembangan selanjutnya tidak hanya memperhatikan ilmu pengetahuan, tetapi juga mengutamakan pembahasan yang berkaitan dengan filsafat dan keagamaan. Faktor inilah yang menyebabkan kaum Nasrani-Suryani banyak yang tertarik mempelajari filsafat dan sebahagian materi filsafat diterjemahkan ke dalam bahasa Suryani. ${ }^{3}$ Bahasa Suryani merupakan bahasa sastra kaum Nasrani yang berada di Persia. Sejak abad ke 3 M, sebagian besar filsafat dan ilmu pengetahuan Yunani diterjemahkan ke dalam bahasa Suryani dan sebagiannya diterjemahkan ke dalam bahasa Persia.

\section{II}

Hubungan alam pemikiran Yunani dengan pemikiran awal permulaan Islam telah terjalin, Islam menerima alam pemikiran Yunani sepanjang tidak bertentangan dengan prinsip-prinsip dasar syari'at. Kenyataan ini terungkap dari suatu riwayat yang menunjukkan keterbukaan Nabi Muhammad menerima alam pemikiran dari luar. Sa`ad Ibn Abi Waqqas ketika sakit, ia dikunjungi Rasulullah. Rasulullah menasehatinya: "Datanglah kepada al-Harits Ibn Kaldah, ia mengetahui soal kedokteran"4 Riwayat ini melukiskan bahwa pada masa jahiliyah orang-orang Arab telah berhubungan dengan bangsa sekitarnya yang telah menerima alam pemikiran Yunani. Kondisi ini telah menjadi dasar utama bagi Islam untuk menerima pemikiran dan sains dari luar.

Transmisi pemikiran filosofis Yunani ke alam pemikiran Islam melalui alam kultural Mesopotamia, Suria, Persia dan Mesir. Akan tetapi transmisinya yang utama adalah melalui alam kultural yang berkembang di Baghdad. Karena Baghdad pada masa itu telah menjadi pusat penerjemahan manuskrip Yunani ke dalam bahasa Arab. Penerjemahan yang dilakukan oleh para ilmuan di bawah kepemimpinan Hunain Ibn Ishak al-Ibadi (809-877 M) mendapat dukungan dari penguasa Abbasiyah khalifah al-Mansur dan Harun al-Rasyid. ${ }^{5}$ Motivasi untuk menerjemahkan filsafat Yunani itu ada hubungannya dengan perkembangan ilmu pengetahuan di masa Dinasti Abbasiyah. Hal ini ditandai dengan inisiatif khalifah al-Ma`mun membangun Bait al-Hikmah $(850 \mathrm{M})$ di ibukota Baghdad. Lembaga yang didirikan ini tidak hanya sebagai pusat penerjemahan, tetapi berfungsi juga sebagai Lembaga Akademi dan Perpustakaan. Bait al-Hikmah sebagai pusat kegiatan ilmiah dipimpin oleh Hunain Ibn Ishak ${ }^{6}$. Semenjak itu penerjemahan manuskrip Yunani dan manuskrip Persia ke dalam bahasa Arab semakin intensif.

Hasil penerjemahan terhadap manuskrip Yunani dan Persia itu memberi pengaruh yang amat besar terhadap ilmuan muslim. Pemikir muslim mengkaji dan meneliti hasil temuan pemikir Yunani, dari pengetahuan yang mereka perdapat itu dikembangkan ke dalam bentuk yang lebih sistematis, sehingga hasil kajiannya membuahkan penemuan-penemuan baru. Dari proses pemikiran ilmiyah yang berjalan secara sistematis itu menjadikan dunia Islam pada masa Abbasiyah mencapai kemajuan yang amat pesat dalam bidang pemikiran dan ilmu pengetahuan. Hal ini ditandai dengan lahirnya filosof Islam seperti Al- 
Kindi, Al-Farabi dan Ibnu Sina. Sedangkan dalam bidang ilmu pengetahuan dikenal Muhammad, Hasan dan Ahmad. Dalam bidang matematika dikenal Jabir, ahli kimia Al-Baruni, ahli astronomi Khawarizmi dan Ibn al-Hitami sebagai ahli optika dan lainnya. ${ }^{7}$

Kemajuan Baghdad dalam bidang pemikiran dan ilmu pengetahuan itu telah memberi pengaruh yang amat besar bagi perkembangan ilmu pengetahuan di dunia Islam lainnya, sehingga pusat peradaban Islam tumbuh di berbagai kota seperti Cordova di Spanyol. Sebagai halnya Baghdad, Spanyol juga melahirkan filosof-filosof muslim terkemuka seperti Ibn Bajjah, Ibn Thufail, Ibn `Arabi dan Ibn Rusyd. Sedangkan ahli medis di antaranya Al-Zahrawi, Ibn Zuhr, juga ahli astronomi dan matematika adalah Ibn Battar8 dan lainnya.

Hal ini menunjukkan perkembangan pemikiran dalam Islam ada hubungannya dengan perkembangan pemikiran filosof Yunani. Akan tetapi kendatipun tidak terdapatnya unsur pemikiran Yunani, pemikiran filosofis Islam tetap akan eksis dalam peradaban manusia, karena sumber ajaran Islam, wahyu sangat menjunjung tinggi penggunaan pendayaan akal di dalam memahami berbagai dimensi alam dan esensi Tuhan. Selain mempelajari esensi alam, manusia juga diisyaratkan oleh wahyu untuk memperhatikan esensi dirinya dengan tujuan agar ia menemukan asal kejadiannya sebagai hasil rekayasa Tuhan terhadap makhluknya.

Dalam al-Qur'an terdapat banyak ayat yang mengisyaratkan tentang poenggunaan akal dan berpikir rasional. Isyarat itu dalam bentuk kata 'aqala, narara, tadabbasa, tafakkara, faqiha, tazakkara, fahima. ${ }^{9}$ Semua kata ini mempunyai hubungan dengan penalaran akal dalam membaca dan memahami ayat-ayat Qur`aniyyah dan ayat-ayat Qauniyah. Dengan demikian berarti alQur`an sejak permulaan diturunkan kepada nabi Muhammad telah memberi dorongan kepada manusia untuk memahami potensi akal. Hal ini berarti juga tanpa pengaruh filsafat Yunani, umat Islam akan dapat secara mandiri mengembangkan pemikiran filosofisnya dalam sistem peradaban Islam.

Kendatipun Islam menempatkan posisi akal pada tempat yang tinggi dan mendapat konfirmasi wahyu, tidaklah berarti Islam menutup diri dari unsur pemikiran Yunani. Hal ini disebabkan filosofis Islam mengambil sebagian besar pemikiran filosofis Yunani seperti Aristoteles, Plato dan filosof lainnya. Pengambilan pemikiran filosof Yunani itu dipandang sesuatu yang wajar, sebab transmisi pemikiran dari suatu generasi ke generasi berikutnya merupakan ketentuan Sunnatullah. Pengaruh pemikiran Yunani itu tidaklah berarti pemikiran filosofis Islam tidak mempunyai wujud sendiri. Filsafat Islam mempunyai esensi yang memadukan antara esensi wahyu dan esensi pemikiran akal seperti yang dinyatakan oleh Al-Farabi, "Agama dan filsafat tidak bertentangan, malahan sama-sama membawa kebenaran". ${ }^{10}$

Filosof Islam berupaya memadukan antara wahyu dengan akal, antara akidah dengan hikmah, antara agama dengan filsafat, dan berupaya menjelaskan kepada manusia bahwa wahyu tidak bertentangan dengan akal. Akidah bila diterangi dengan sinar filsafat akan menetap didalam jiwa. Agama jika bersaudara dengan filsafat akan menjadi filosofis sebagaimana filsafat menjadi religius. Karena filsafat Islam oleh lingkungan di mana ia hidup dan tidak 
terlepas dari kondisi yang melingkupi. Dengan demikian filsafat Islam adalah filsafat religius-spiritual.

Menurut filosof Islam terkemuka Al-Kindi, antara wahyu dan filsafat tidak bertentangan. Argumen yang dibawa al-Qur`an lebih meyakinkan dari argumen yang ditimbulkan filsafat. Kebenaran yang diberitakan wahyu tidak bertentangan dengan kebenaran yang dibawa filsafat. Filsafat bagi Al-Kindi adalah pengetahuan tentang yang benar, sedangkan agama tujuannya adalah menerangkan apa yang benar dan apa yang baik. Agama di samping mempergunakan wahyu juga mempergunakan akal. Filsafat yang menggunakan daya penalaran akal juga mencari kebenaran. Filosof Islam memakai wahyu dan akal dalam mencapai hakikat kebenaran.

\section{III}

Kemajuan yang dicapai oleh dunia Islam dalam bidang pemikiran dan ilmu pengetahuan telah diketahui oleh dunia internasional pada abad ke 11 melalui informasi-informasi ilmiah dan komunikasi diplomatik antara Timur dan Barat. Semenjak itulah orang-orang Nasrani Barat mempunyai kecendrungan untuk mempelajari filsafat dan ilmu pengetahuan dari dunia Islam. Upaya itu mereka lakukan dengan cara menerjemahkan literatur filsafat dan ilmu pengetahuan hasil karya filosof dan saintis Islam ke dalam berbagai bahasa Eropa. ${ }^{11}$ Usaha penerjemahan ini dilakukan oleh para alumni dari berbagai universitas Islam yang berada di Spanyol, Cicilia dan dari universitas Islam di Timur. Kegiatan penerjemahan ini berlangsung selama dua abad dari abad ke 12 sampai abad ke $13 \mathrm{M}$.

Kegiatan penerjemahan itu semakin meningkat aktifitasnya semenjak didirikan lembaga penerjemahan di Toledo. Lembaga ini selain sebagai pusat penerjemahan, juga berfungsi sebagai akademi yang mempelajari berbagai bidang ilmu pengetahuan dan filsafat. Di antara alumni yang berasal dari akademi tersebut antara lain Raymon Martin dan Raymon Luu (1316 M). Sedangkan penerjemah yang utama yaitu Ibrahim Ibn Daud (1180 M) bangsa Yahudi, Herman berbangsa Jerman (1272 M), Gerard bangsa Itali (1187M) dan Dominic Gandsalinos (1150 M).12

Usaha ilmiah dalam bidang penerjemahan ini mendapat dukungan dari pihak penguasa politik Sicilia Kaisar Frederich II. Kaisar mengirim para intelektual untuk mencari manuscript karya filosof dari saintis Islam di berbagai lembaga dan Universitas Islam di Timur. Diantara manuscript yang menarik perhatian orang-orang Eropa adalah karya Ibn Rusyd. Kaisar Frederich II memerintah Michael scott $(1235 \mathrm{M})$ untuk menerjemahkan dan kemudian hasil terjemahan tersebut dikirim keberbagai Universitas di Barat. Faktor penerjemahan inilah yang mempercepat transmisi pemikiran Islam ke dunia Kristen di Barat.

Para Intelektual Barat pada mulanya menaruh perhatian hanya pada filsafat, akan tetapi dalam perkembangan selanjutnya perhatian mereka tertuju pada ilmu pengetahuan, terutama literatur kimia, matematika, astronomi, botani, kedokteran, dan berbagai bidang ilmu pengetahuan lainnya. 
Hampir semua karya saintis Islam terkemuka diterjemah ke dalam bahasabahasa Eropa. Seperti karya Al-Khawarizmi (780-85 M) tentang matematika diterjemah oleh Gerard dari Kremana kedalam bahasa latin dan dijadikan sebagai buku pegangan oleh berbagai Universitas di Eropa sampai abad ke 14 . Selain itu karya Al-Farghani, Al-Mukdil Ila 'Ilm Hayat Al-Aflak, diterjemahkan kedalam bahasa latin oleh Yohanes Hispalensis dan Gerard tahun 1935 M. Karya Battani yang membahas astronomi sebagai kritik dan koreksi terhadap karya Platomeus mengenai orbit bulan dan planet lainnya diterjemahkan kedalam bahasa latin oleh Lalande dan dikenal dengan De Scientia Stellarum. ${ }^{14}$

Orang Eropa mengambil juga dari Islam ensiklopedi besar tentang ilmu kedokteran karya Ar-Rozi (865-925). Karya Ar-Razi ini dikenal dengan Continens, merupakan rujukan utama dalam bidang kedokteran selama sepuluh abad di Barat. Sementara itu karya Ar-Rozi mengenai penyakit cacar (variol) yang terbit abad X, telah dicetak ulang sebanyak 40 kali dari tahun 1498-1866 M15. Karyakarya Ar-Rozi ini mempunyai pengaruh yang sangat beasar terhadap ilmu kedokteran di Eropa.

Ibnu Sina [Avicena] (980-1178 M) yang dikenal sebagai filosof dan saintis, mempunyai karya yang cukup baik. Diantara karyanya yang sangat menarikperhatian para intelektual Eropa adalah karyanya dalam bidang kedokteran. Karyanya Al-Qanun fil Thibbi, merupakan ensiklopedia besar selama delapan abad, dan karyanya ini diterjemahkan kedalam bahasa latin oleh Gerard de Gremone (w $1178 \mathrm{M}$ ).

Dokter mata terkemuka Ibn Haitam (Al-Hazen, 965-1039 M) mempunyai karya dalam bidang kedokteran Opus Majus menjadi rujukan utama bagi Roger Bacon dalam mengembangkan ilmu kedokteran di Eropa. ${ }^{16}$ Semua karya hasil eksperimen dokter muslim itu menjadi bahan rujukan bagi dokter-dokter Eropa dalam mengembangkan ilmu kedokteran di abad modern.

Dalam bidang ilmu alam, orang-orang barat juga mengambil dari Islam. Sebab para saintis Islam telah mengadakan berbagai penelitian di berbagai bidang, seperti ilmu hewan, ilmu tumbuh-tumbuhan, antropologi, dan geologi. Para ahli tersebut antara lain Al-Jahri yang menulis Kitabu Al-Haiwani, karyanya ini mempunyai pengaruh yang cukup besar terhadap perkembangan ilmu selanjutnya. Selain itu Abu Yahya Al-Qurwani dan Ikhwan Al-Safa' yang menuliskan tentang hewan dan manusia serta ciptaan Tuhan terhadap alam, ${ }^{17}$ mempunyai pengaruh pula terhadap pemikir dan saintis Barat pada abad pertengahan dan abad modern.

Filosof Islam yang sangat berpengaruh terhadap perkembangan pemikiran dan ilmu pengetahuan di berbagai universitas di Barat adalah Abu al-Walid Muhammad Ibn Muhammad Ibn Rusyd (1126-1198). Ia merupakan filosof muslim yang paling banyak menerjemahkan manuskrip Aristoteles. Karyanya yang paling terkenal adalah Tahafut Al-Tahafut, sebagai jawaban terhadap kritik Al-Ghazali dalam karyanya Tahafut Al-Falasifah. ${ }^{18}$ Karya Ibn Rusyd itu membela pemikiran filosof tentang berbagai problematika filsafat, sementara karya AlGhazali mengkritik serta memandang para filosof telah menggunakan logika yang salah dalam membahas berbagai esensi persoalan filsafat.

Karya Ibn Rusyd menjadi sumber rujukan utama bagi Aristoteleonisme Eropa abad pertengahan dan untuk waktu lama Ibn Rusyd mempengaruhi 
pemikiran filosof Eropa. Kuatnya pengaruh Ibn Rusyd itu kata Ibrahim Madhkour, dikarenakan kuatnya dorongan Frederich II untuk menyerap pemikiran Ibn Rusyd serta hasil komentar Ibn Rusyd tentang pemikiran filosofis Aristoteles. Frederich II juga menganjurkan Michael Scott untuk menerjemahkan karya Ibn Rusyd ke dalam bahasa latin abad ke $13 \mathrm{M}$. Kemudian hasil terjemahan itu dikirim ke berbagai universitas di Eropa.

Sekitar abad ke $12 \mathrm{M}$, filsafat Ibn Rusyd telah berkembang dengan pesatnya di Eropa, sehingga timbul aliran Anirusme. Aliran ini mendapat tantangan dari gereja, karena filsafat Ibn Rusyd sangat bertentangan dengan ajaran kristen. Untuk membendung filsafat Ibn Rusyd ini pihak gereja mengeluarkan berbagai keputusan pada tahun 1210 M. Di dalam Council of Paris yang melarang mempelajari filsafat Aristoteles dan Ibn Rusyd. Kemudian Kradinal Paris Legate Raber of causon di tahun 1215 M mengeluarkan larangan terhadap anirusme dan memberi sanksi bagi mereka yang mempelajari filsafat Ibn Rusyd. Larangan itu diperkuat oleh Paus di Vatikan. Keadaan ini menunjukkan betapa kuatnya pengaruh Ibn Rusyd di bumi Eropa, dan semakin kuatnya pencegahan pemikirannya yang diplopori oleh Paus dan Kradinal, yang mengalami kehilangan pengaruh diantara pengikutnya di Barat.

Anirusme, pendukungnya terdiri dari orang-orang dari kalangan intelektual, mereka sangat tertarik pemikiran Ibn Rusyd yang memadukan antara agama dan filsafat, di antara keduanya mempunyai tujuan yang sama dalam mencari kebenaran. Pemikiran semacam ini tidak dapat diterapkan di Barat, karena ajaran Kristen merupakan ciptaan manusia yang sulit diperbandingkan dengan pemikiran rasional. Meskipun terjadi pertentangan yang tajam antara pihak gereja dengan anirusme, akhirnya pihak gereja terpaksa menyesuaikan diri dengan perkembangan pemikiran yang digerakkan oleh anirusme. Faktor inilah yang dijadikan dasar untuk menyatakan anirusme peletak landasan bagi perkembangan pemikiran-pemikiran dan ilmu pengetahuan dalam peradaban Barat. Hal ini diakui sendiri oleh para pemikir Barat, seperti Rom Landau. Dari orang Arablah Eropa belajar berpikir secara objektif dan lurus, belajar berlapang dada dan berpandangan luas. Inilah dasardasar yang jadi pembimbing bagi Rennaisance dan yang menimbulkan kemajuan dan peradaban Barat. Pengakuan jujur juga dikemukakan oleh Anthony Mutting19. Demikianlah hal-hal yang dicapai pada zaman kemajuan dalam bidang pemikiran dan ilmu pengetahuan Islam yang dimulai dari hari-hari pertama pemerintahan Bani Abbas dan inilah yang memberikan inspirasi kepada timbulnya revolusi ilmiah di Eropa abad ke tujuh belas.

Pengakuan jujur oleh sebagian pemikir Barat ini sebagai bukti kongkrit, bahwa pemikiran dan sain produk Islamtelah memberi sumbangan yang sangat besar bagi kemajuan peradaban Eropa. Jika tidaklah karena Islam, bangsa Eropa sulit untuk memperoleh kemajuan dalam bidang pemikiran dan ilmu pengetahuan, serta untuk mencapai peradaban modern. 
Hingga kini, masih kuat anggapan dalam masyarakat luas yang mengatakan bahwa "agama" dan "ilmu" adalah dua entitas yang tidak bisa dipertemukan. Keduanya mempunyai wilayah sendiri-sendiri, terpisah antara satu dan lainnya baik dari segi objek formal-material, metode penelitian, criteria kebenaran, peran yang dimainkan oleh ilmuan maupun status teori masingmasing bahkan sampai masuk ke institusi penyelenggaraannya. Dengan kata lain, ilmu tidak mempedulikan agama dan agama tidak pula mempedulikan ilmu. Praktek kependidikan dan aktifitas keilmuan sekarang ini mempunyai gambaran dengan berbagai dampak negatif yang ditimbulkannya dan dirasakan oleh masyarakat luas. Oleh karena itu, anggapan yang salah perlu dikoreksi dan diluruskan. ${ }^{20}$

Dalam sejarah kependidikan Islam, telah terpola pengembangan keilmuan yang bercorak integralistik-ensiklopedik yang ditokohi oleh para ilmuan seperti Ibnu Sina, Ibnu Rusyd, Ibnu Khaldun yang berhadapan dengan pola pengembangan keilmuan agama yang spesifik-parsialistik di sisi lain yang dikembangkan oleh para ahli hadis dan ahli fiqih. Keterpisahan antara keduanya dan sebab-sebab lain yang bersifat politis-ekonomis, berakibat pada rendahnya mutu pendidikan dan kemunduran dunia Islam pada umumnya. Dalam ketiga revolusi peradaban manusia, yaitu revolusi hijau, revolusi industri dan revolusi informasi tidak satupun ilmuan muslim tercatat namanya dalam lembaran tinta emas pengembang ilmu pengetahuan. ${ }^{21}$ Perkembangan dan pertumbuhan ilmuilmu sekuler sebagai simbol keberhasilan Perguruan Tinggi bukan yang tercabut dari nilai-nilai akar moral dan etnik kehidupan manusia di satu pihak dan perkembangan serta pertumbuhan Perguruan Tinggi Agama yang hanya menekankan ilmu-ilmu keagamaan dan teks-teks keislaman normative era klasik dengan berbagai dampaknya pada penciptaan tenaga terampil dalam dunia ketenagakerjaan di lain pihak, sehingga menjadikan keduanya mengalami proses pertumbuhan yang tidak sehat serta membawa dampak negatif bagi pertumbuhan dan perkembangan kehidupan sosial-budaya, sosial-ekonomi, sosial-politik dan sosial-keagamaan.

Dalam sejarah hubungan ilmu dan agama di Barat, pemimpin gereja menolak teori heliosentris Galileo atau teori evolusi Darwin. Pemimpin gereja membuat pernyataan-pernyataan yang berada di luar bidang kompetensinya. Sebaliknya Issac Newton dan tokoh ilmu-ilmu sekuler yang lain menempatkan Tuhan hanya sekedar sebagai penutup sementara lobang kesulitan (to fill graps) yang tidak terpecahkan dan terjawab oleh teori keilmuan mereka, sampai tiba waktunya diperoleh data yang lebih lengkap atau teori baru yang dapat menjawab kesulitan tersebut. Begitu kesulitan itu terjawab, maka secara otomatis invertensi Tuhan tidak lagi diperlukan. Akhirnya Tuhan dalam benak para ilmuan "sekuler" hanya ibarat pembuat jam. Begitu alam semesta ini selesai diciptakan, ia tidak peduli lagi dengan alam raya ciptaan-Nya dan alam semesta pun berjalan sendiri secara mekanis tanpa campur tangan Tuhan. Sementara dalam dunia Timur yang dalam hal ini dunia Islam, pengajaran ilmu-ilmu agama Islam yang normative-tekstual terlepas dari perkembangan ilmu pengetahuan dan teknologi, ilmu-ilmu sosial, ekonomi, hukum dan humaniora pada umumnya. Perbedaan itu semakin hari semakin jauh dan membawa akibat yang tidak nyaman bagi kehidupan dan kesejahteraan umat manusia. Pola pikir 
seperti ini menjadikan manusia terasing dari nilai-nilai spiritualitas-moralitas, terasing dari dirinya sendiri, terasing dari keluarga dan masyarakat sekelilingnya, terasing dari lingkungan alam dan ragam hayati yang menopang kehidupannya serta terasing dari denyut nadi lingkungan social budaya sekitarnya. Singkatnya, terjadi proses dehumanisasi baik pada tataran kehidupan keilmuan maupun keagamaan.

Dari sini tergambar bahwa ilmu-ilmu sekuler yang dikembangkan di Perguruan Tinggi Umum dan ilmu-ilmu agama yang dikembangkan di Perguruan Tinggi Agama secara terpisah seperti yang sekarang ini berjalan sedang terjangkit krisis relevansi, mengalami kemandegan dan kebuntuan dan penuh dengan bias-bias kepentingan. Dari latar belakang seperti itu, gerakan rapproachment antara dua kubu keilmuan adalah merupakan keniscayaan. Gerakan rapproachment disebut juga dengan gerakan penyatu atau reintegrasi epistemology yang merupakan keniscayaan dan mutlak diperlukan untuk mengantisipasi perkembangan-perkembangan yang serba kompleks dan tak terduga pada milenium ketiga serta tanggung jawab kemanusiaan bersama secara global dalam mengelola sumber daya alam yang serba terbatas dan sumber daya manusia Indonesia yang berkualitas sebagai Khalifah fi al-ardli.

Perguruan Tinggi Agama khususnya IAIN, secara sadar harus berani mengkaji ulang visi, misi dan paradigma keilmuan yang pernah dibangunnya selama 50 tahun. Begitu juga Perguruan Tinggi Umum yang sudah mapan dan berjalan selama ini. Ide dan usulan perlunya dikembangkan ilmu-ilmu social profetik dan kajian agama secara kontekstual di Perguruan Tinggi Umum merupakan tanda adanya keprihatinan yang serius tentang arah pengembangan dan tujuan pembelajaran ilmu-ilmu umum pada Perguruan Tinggi Umum yang telah berjalan selama 50 tahun belakangan ini. Bangunan ilmu pengetahuan dan dikotomik antara ilmu pengetahuan umum dan ilmu pengetahuan agama harus diubah menjadi bangunan keilmuan baru yang lebih holistik-integralistik atau paling tidak bersifat komplementer. Tujuan IAIN perlu diorientasikan pada lahirnya sarjana yang memiliki tiga kemampuan sekaligus, yaitu kemampuan menganalisis secara akademik, kemampuan melakukan fungsionalnya, kemampuan memimpin sesuai dengan tuntunan persoalan kemasyarakatan, keilmuan maupun profesiyang ditekuninya dalam satu tarikan nafas etos keilmuan dan keagamaan.

Transmisi pemikiran dan ilmu pengetahuan pada dasarnya membentuk garis lingkaran bundar, dari peradaban Timur ke peradaban Yunani, kemudian berkembang dalam peradaban Islam dan selanjutnya ditranmisi kedalam peradaban Eropa dan akhirnya membentuk suatu peradaban modern yang bersifat global.

\section{Catatan akhir:}

${ }^{1}$ Ahmad Amin, Fajar al-Islam, Kairo : Mardhah Misriyyah, 1975, hal. 125

2 Ibid, hal. 127 
Al-Fikra: Jurnal Ilmiah Keislaman, Vol. 4, No. 1, Januari-Juni 2005

\author{
${ }^{3}$ Ahmad Amin, Loc.cit, hal. 131 \\ ${ }^{4}$ Ibid \\ ${ }^{5}$ Harun Nasution, Islam Ditinjau Dari Berbagai Aspeknya, Jakarta: UI Press, 1985, hal. 46
}

${ }^{6}$ De Boer.T.J, Tarikh al-Falsafat Fi al-Islam (cd) Muhammad Abdul Hadi Abu Raidah, Kairo: Lajnah al-Fa' lif wa al-Tarjamah wa al-Hasyr,1938,hal. 23

7Philip K. Hitti, Islam A Wayof life, Minneopolis University of Minnsota Press, 1969, hal.108

8 Ibrahim Madhkour, Fi al-Falsafah al-Islamiyah, Kairo: Pan al-Ma`ruf bi Nishr, 1976, hal. 54

${ }^{9}$ Harun Nasution, Filsafat dan Mistisisme Dalam Islam, Jakarta: Bulan Bintang, 1973, hal. 11

${ }^{10}$ Ibid

11 Ahmad Syalabi, Tarikh al-Islami wa al-Hadarat al-Islamiyah, IV, Kairo: Maktabat al-Nahdah al-Misriyah, 1979, hal. 105-106

12 Ibrahim Madhkour, op.cit, hal. 128 hal. 109.

14Phillip K. Hitti,, Islam A Way Of Life, Minneapolis, University of Minnosota Press, 1969,

15De Boer. T.J. Tarikh Al-Falsafah Fi Al-Islam, (ed) Muhammad Abdul Hadi Abu Raidah, Kairo: Lajnah Al-Ta'lif Wa Al-Tarjamah Wa Al-Hasyr, 1938, hal. 89-91

16Sayyed Husain Nasr, Science and Civilization in Islam, Cambridge, Harvard University Press, 1968, hal. 210

17Harun Nasution, Akal dan Wahyu dalam Islam, op.cit, hal. 66

18De Boer, op.cit, hal. 225

19Harun Nasution, Akal dan Wahyu Dalam Islam, (Jakarta. UI Press, 1986), hal. 70

${ }^{20}$ Ian G. Barbour, Issues in Science and Religion, New York: Harper Toarchbooks, 1966, hal.1-2

${ }^{21}$ Mahathir Muhammad, Globalisation and the New Realities, Selangor: Pelanduk Publications, 2002, hal. 54 